\title{
A reflection on Vuyani Vellem's longing for liberation: A spirituality of life and freedom
}

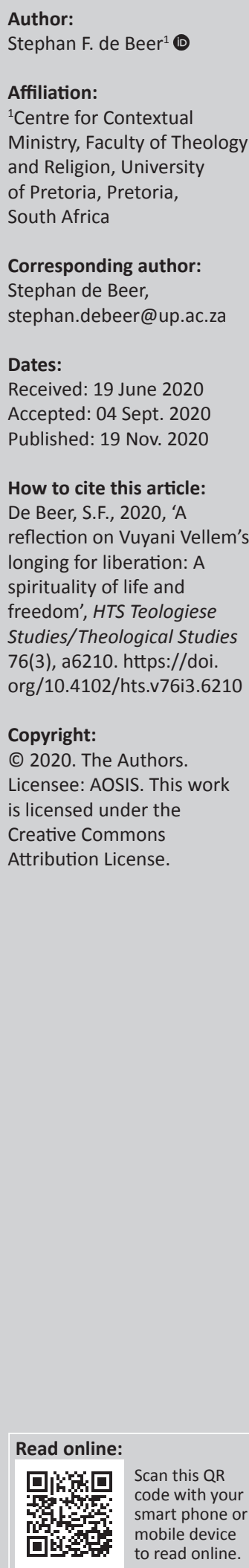

Vuyani Vellem was insistent on fostering a spirituality that could ground and sustain resistance of death as expressed in multiple unfreedoms, and the quest for life and freedom in abundance. After naming a number of themes evident in the life of Vuyani - ranging from racism and pigmentocracy to the managerialist university and the shackled church - this article traces his reflections on a spirituality that embraces the cross, resurrection as rebellion and imvuselelo [revival] as the iziko [fire] that births a new political community. It considers the imvuselelo as both an exorcism and a reconstruction. In conclusion, the intersectionality of violences and oppressions, increasingly addressed in his work, is touched upon. And the charge he left us with, to connect spirituality and liberation - as moral imperative and integrative force - is considered for embrace.

Contribution: This article contributes an appreciative reflection on the spirituality of Vuyani Vellem that undergirded his Black Theology of Liberation. In contemporary contestations and discourses on race and racial justice, whiteness and oppression, and decoloniality, what is often absent is a clearly articulated spirituality of black liberation. Vellem helps us with that.

Keywords: spirituality; death and life; unfreedom and freedom; imvuselelo; resurrection as rebellion; intersectionality.

\section{Spirituality of black liberation}

\author{
I wish I knew how it would feel to be free \\ I wish I could break all the chains holding me \\ I wish I could say all the things that I should say \\ Say 'em loud say 'em clear \\ For the whole wide world to hear. ${ }^{1}$
}

Movements and proponents of liberation need a spirituality to sustain their long and difficult journeys. Without spirituality, liberation can fall prey to the seduction of co-option into intellectual jargon, or neo-orthodox correctness, whilst being void of the liberatory substance potent enough to make real and deep change.

Vuyani Vellem, already in his doctoral dissertation in 2007, but ever clearer and more passionately in recent times, explored a spirituality undergirding the journey of liberation. One of the ways in which he unpacked it was to bring spirituality and consciousness into conversation. According to Vellem (2007:289), '[c]onsciousness and spirituality, in our paradigm, are two sides of the same coin'. And yet, one could perhaps argue that these are not always regarded as two sides of the same coin. Dominant spiritualities as well as political movements are often guilty of maintaining and perpetuating (false) dichotomies that separate or disintegrate spirituality and consciousness from each other.

It then becomes possible to speak about a spirituality without a consciousness (at least in a sociopolitical or concrete historical sense) and also of a consciousness (a rational, analytical construct) without a spirituality.

In a similar way, using different terms, Jon Sobrino's 1988 work on spirituality and liberation sought to hold spirit and practice together:

Without spirit, practice can always degenerate. Without practice, spirit will remain vague, sidelined, even alienating. (Sobrino 1988: xi-x)

1.From the song by Nina Simone, 'I wish i knew how it would feel to be free', recorded on her 1967 album, Silk \& Soul. I never had a chance to speak to Vuyani about Nina Simone, an artistic icon of the civil rights' revolution. Her lyrics became the battle cry for sociopolitical emancipation of black people, and the poetic source for sustaining many a liberation struggle. She herself longed for personal and mental freedom until the day she died.

Note: Special Collection entitled VukaniBantuTsohangBatho - Spirituality of Black Liberation, sub-edited by Fundiswa Kobo (UNISA) and Rothney Tshaka (UNISA). 
If we consider spirituality, consciousness and practice, I suppose that both Sobrino and Vellem would have insisted on their intimate interconnection and that separating these categories impoverishes them, and even reduces them, to what they ought not be. It is in deeply embodied actions of solidarity that the Spirit has an opportunity to awaken a new consciousness. Spirituality and consciousness that are becoming aloof from daily realities of death and pain become useless exercises in themselves. The poor cannot be sheltered by their utterances, however radical or mystical they may sound, if not informed by or translated into practice.

Vellem connected these closely and insisted that a proper spirituality of liberation needs to be fostered, for various reasons, amongst which is energising the movement, but also as an antidote to consciousness that gets embodied in unethical and self-serving ways, because of lack of groundedness in a spirituality of life and freedom. Liberation movements that lose their grounding in such a spirituality could become mediators of new forms of death or oppression. It then becomes a matter of exchanging one dominant narrative for another, but freedom which is at the core of a liberationist longing remains elusive, now shackled in neoorthodox constructs. It is to change intellectual sides without changing the playing fields radically. It is to play the same game but from a different vantage point - even if the rhetoric is to the contrary - instead of changing the game altogether.

The purpose of this article is not to provide a coherent overview of Vellem's spirituality as lived, articulated or longed for. Rather, it is a personal reflection coming from my own engagements with Vuyani, both at personal and collaborative levels, but also from studying some of his writing. It is an attempt to make sense for myself of some of the central threads in Vuyani's thought, both in drawing from the deep and wise wells it represents and in passing it onto next generations committed to find and foster a spirituality 'embracing the cross' (Vellem 2018).

\section{Death and unfreedom}

I wrote this article in the context of coronavirus disease 2019 (Covid-19). And as I almost wrapped it up, the killing of George Floyd took place in Minneapolis, breaking the proverbial camel's neck and unleashing anger and civil protest and disobedience across the cities of the United States of America at a scale last seen in 1968. These protests soon found resonance in cities across the world.

In South Africa, solidarity with the eruption of anti-racism protests was obvious, as experiences of smothering whiteness hovering over our institutions and preventing the deepest forms of freedom longed for still remain real. An additional outcry in South Africa, which is very tame in comparison to the events in North America, has become the killings of 12 black persons - all unarmed - at the hands of law enforcement agencies during lockdown for Covid-19. As I write this article, none of the officers have been apprehended and no justice served for any of the victims and their families. The ways in which black lives are reduced to nothingness, even by black law enforcement agencies in South African communities, speak about the deeply entrenched legacies of white superiority and the effective ways in which apartheid policies and education have caused internalised notions of superiority and inferiority.

I often wondered what Vuyani's message to us would have been at this time - how would he have encouraged black Christians and what would he have said to white Christians, right now?

The virus of Covid-19 has spread across the world, killing over 400000 people so far, between 22 January and 12 June 2020 (Roser et al. 2020). The impact of the virus has gone way beyond that, affecting people and countries economically and socially, sometimes in devastating ways; altering the nature of institutions; and giving nature an unexpected break.

The virus of racism has infiltrated not only the hearts and minds of people for centuries, but has also been institutionalised to the point of it being difficult to see the wood for the trees. So, pervasive is the institutionalisation of racism that those in positions of power are unable or unwilling to detect the ways in which its tentacles have infiltrated our decision-making processes, our good judgement and our complicity in perpetuating structural exclusions.

There are also critical voices sounding up in the face of the global protest movement. Why, do they ask, are there not similar groundswell of resistance against gender injustice and the violences perpetrated against women or the LGBTIQ+ community? Why is the movement that addresses the destruction of the planet still so tentative, especially in the ranks of people of faith?

Just as we were preparing to attend anti-racism and antirepression Vigils in our city in the past week, news came through about the senseless killing of Tshegofatso Pule, 28 years old, and 8 months pregnant, by her boyfriend. Between April 2018 and March 2019, 3000 South African women were killed by partners (seven women a day) (Khumalo 2019). It (such as homelessness, poverty and inequality) became part of the landscape without even a frown any longer. Why, indeed, does the death of 3000 women in one country in 1 year, at the hand of their male partners, not provoke the same indignation as the killings of George Floyd, or Collin Khoza?

In his work, Vellem increasingly appreciated the insights from other paradigms and pleaded for an intersectional understanding of oppressions, correcting or expanding the agenda of a Black theology of liberation to take on board not only issues of race any longer, but more deliberately also issues of economic injustice, gender oppression, xenophobia and Afrophobia and the destruction of the earth.

These viruses, unfreedoms or oppressions, when denied, turn into destructive killing machines. Even if death is not dealt physically, which it often is, then the last breath is squeezed from people psychologically, mentally, culturally 
and spiritually. In many places, institutionalisation of racism, sexism or classism leave brilliant people exasperated, crying out, often quietly to themselves and sometimes, louder, to others they trust, saying: 'I can't breathe!'.

Freedom is denied, to the point of being unable to breathe, until we die.

At this point, in a very introductory way, I name six of the unfreedoms dealing with death, which I heard Vuyani often reflected upon. It is by no means exhaustive of the breadth of prophetic insight and clarity with which he named death amongst us. It also does not include his grasp of the intersectionality of violence and oppression that I will refer to later in the article.

\section{Racism and pigmentocracy}

As a Black Theology of Liberation, the category of race obviously took centre stage in Vellem's work. He distinguished between racism and white superiority in an interview with Martin Laubscher (2018):

\begin{abstract}
... While supremacy might be understood as physical antics of racism, superiority is much deeper than that, it is spiritual!

This is what sustains and maintains racism... the spirit of superiority, the doubt of the humanity of others... It is probably only a different consciousness that can change this spirit, a different mindset, indeed a different spirit which, in the terms and grammar of BTL, is opened up by spaces and experiences of Blackness, woundedness or the wretched of this world. Racism is a spirit that worships an idol - superiority - not the God of the oppressed, a Christianity that ruptures from a religion of the powerless. (pp. 7-8)
\end{abstract}

Because of his conviction that white supremacy, and its resultant racism, is a spiritual matter, he concurs with Kritzinger's $(1988,1990)$ assertion that it requires a spiritual conversion - 'a different consciousness', and, Vellem would propose, that such was indeed a possibility that could be mediated by spaces in which the woundedness of blackness and the wretched of the world and the profound and lifedestroying effects of (white) superiority are experienced.

Vellem also went to lengths, both in his writing and in his speech and personal relationships, to challenge the idea that Black Theology of Liberation was itself pigmentocratic (cf. Laubscher 2018). Vellem consistently distinguished between pigmentation and consciousness. He held, in my understanding, that pigmentation did not guarantee consciousness, and that those who equated pigmentation with consciousness, or lack thereof, were themselves guilty of a pigmentocratic mindset. At the same time, consciousness was also not the preserve of a certain pigmentation only because that too would be to subscribe to a pigmentocracy. Vellem cut through this, insisting on a spiritual conversion and a revival of the soul, that would embrace a consciousness shaped by the cross in its solidarity with the wretched of the earth.
After his death, I tried to remember him in this way (De Beer 2019):

Vuyani insisted that we are invited into a depth of consciousness that went beyond pigmentation - that invaded the crevices of the soul and the mind, to replace depths of prejudice with new and brave imaginaries. He modelled, to us, the quest for a true humanity.

\section{Neoliberal capitalism and economic oppression}

Vellem (2015b) traced the close relationship between racism and economic exclusion today characterised by neoliberal forms of capitalism:

The underside of modernity is an adverse catastrophic experience of total and violent exclusion of black Africans that mirrors the root connection between economics, racism and the current neocolonial models of economic management. (pp. 2-6)

He writes capitalism's 'symbiotic relationship with racial exploitation' echoing what Cone (1980:16) asserted when he said, 'I do not think that racism can be eliminated as long as capitalism remains intact'.

Part of the task of Black Theology of Liberation lies precisely in its critique of the intersection between 'capitalism, white supremacy, neoliberal ideology, neoliberal democracy' and how this dominant matrix is seeking to valorise the 'experience of those excluded and now killed by the current civilization' (Vellem 2015a:182). Vellem sought to show just how the neoliberal capitalist project coupled with institutional racism further entrenched white superiority and black exclusion.

In reflecting on South Africa's National Development Plan (NDP), Vellem (2014c) critiqued it as an expression of neoliberal capital, in how it succumbed to the 'myths of neoliberal economics'. The expansion of capitalist growth, at the expense of radical economic inclusion and the sanctity of creation, remained foremost in the objectives of the NDP, even if not branded as such. Vellem's critique came through the lens of his 'sacramental view of work' and the economy that completely contradicts the instrumentality of work, in the interest of profit that is not shared with the worker.

Vellem (2015a), in an insightful and rather disturbing way, shows how the neoliberal project of economic oppression and exclusion is kept intact by what he calls a 'neoliberal religiosity' or 'neoliberal spirituality':

One of the deadliest weapons of the religiosity of Empire is to dichotomize reality ... The interpretation of the gospel with a dichotomizing epistemological framework keeps the poor dying, while exhorting them to wait for heaven. It throttles and dismembers the body of the oppressed, while promising the salvation of the spirit. The Christianization of this dichotomizing epistemological framework places the gospel of Jesus Christ squarely into the fetish of neoliberal religiosity. Neoliberal religiosity lives on the spirit of the poor, but does not feed the spirit of the poor ... Neoliberal spirituality bodily employs and extracts living work from the poor, but it does not provide life for the poor. (p. 184) 


\section{The managerialism of the university}

The university has become a custodian of the neoliberal project, and its myths not only boldly proclaimed but also intrinsically embodied in the institutional structures, managerial models and functionality of staff in relation to profit. Knowledge has become commodified and embraced in an almost uncritical manner by university hierarchies globally.

Although this was a passionate eruption of his in the corridors and meeting spaces of the university, unfortunately, Vellem did not articulate his critique of the neoliberal university enough in his writings. Those who worked with him will know how penetratingly acute his critique was of the managerialist university, shaped by neoliberal capitalist ideals, and enslaving the academic project - and university staff - to its core. At times, he rebelled against top-down dictates that had little to do with the soul and integrity of the university, and everything with the whims of a neoliberal agent of capital. It even got him into trouble at times.

He would frame his critique in reference to Dussel's (2011:111) description of the 'cynical-managerial reason... of capitalism', showing how the university has lost its right of independent existence outside of the capitalist project to which it became a slave.

Eagleton (2010), to whom Vellem often refers in his writings, spoke about this as 'the death of universities', describing how the role of the academy changed to that of serving the status quo, instead of challenging it in the name of justice, tradition, imagination, human welfare, the free play of the mind or alternative visions of the future'.

\section{The shackledness of the church}

In a collection of articles in 2015, Vellem entitled his contribution simply 'Unshackling the church'. Elsewhere I reflected on it, writing, '[h] never gave up on the church, but was committed to its unshackling from colonial, pigmentocratic, and culturally oppressive structures, and the death it dealt' (De Beer 2019).

To Vellem (2015c), such unshackling - or liberation - required a definite methodology:

To unshackle the church, a subversive model of ecclesiology is the starting point wherever it could be identified. For a Black Theology of liberation, the subversive character of the church is in the memory of the miserable, the condition of blackness. (p. 5)

In a memorial piece that we wrote on the website of the Centre for Contextual Ministry at the University of Pretoria, I tried to capture it in this way (De Beer 2019):

Without deliberately incarnating itself in the memory and experience of 'the miserable', Vuyani held, 'ecclesiology in South Africa remains pie in the sky'. This is a foundational challenge of Vuyani's to the theology we do: are we locating ourselves in the experience of 'the miserable'; or do we peddle 'pie in the sky' constructs with little liberatory substance?
He called for ecclesiologies shaped from the experiences of 'the miserable', without which the subversive character of church and discipleship is lost, leaving only faint traces of what the Jesus movement was supposed to be.

An integral part of the church's shackled nature is the way in which Western Christianity, with its dichotomising and 'dominating salvationist paradigm of religion' (Vellem 2014b:3-7), has succeeded in the 'cultural subjugation of the black Africans who were colonized' (Vellem 2014b). Black Theology of Liberation has as an important psycho-sociocultural function to fulfil. Political and economic subjugation often follows on cultural or mental subjugation. Vellem refers to Thiong'o's (2009) assertion that cultural domination was even more dangerous ' $[B]$ ecause it is more subtle and its effects long-lasting'.

\section{The co-option of African, liberationist and Black theological symbols and proponents}

Another consistent thread in Vellem's (2014b) work is a lament over the co-option of African, liberationist or Black theological symbols and proponents. I make sense of this in three ways.

Firstly, the neoliberal university, or the church of capital and pigmentocracy, appropriate symbols coming from African religious heritage, liberation or Black theology, shrewdly domesticating it until it lacks substance. Vellem (2014b), for example, wrote about it with reference to the use of lekgotla for annual break-away meetings in our Faculty of Theology and Religion, or government planning deliberations, suggesting that the mere use of this term - without shaping these public spaces to resemble the meaning and values of a lekgotla in the traditional sense - instead of it serving to Africanise it becomes an offence.

A second dangerous and disingenuous way in which this occurs is when institutions choose to honour key figures who were part of, say, the liberation struggle in South Africa, projecting the institution thereby as an ally of that which this person taught or embodied, whilst, in reality, the agenda and content of the person honoured is never taken on board. This kind of co-option is void of integrity and needs to be exposed for what it is. Unless institutions place themselves under scrutiny through the lenses of those they seek to honour, allowing such lenses to help them with personal and institutional self-reflection, and a resolve to go on new journeys of self- and institutional transformation, which could start to embody the work of those they honour, such vain and false projects under the guise of transformation should never be embarked upon.

A third way, and Vellem warned about this, is when leading voices of African, Black or liberation theologies, find themselves in positions of authority at various institutions. The dangers of co-option into institutional constructs that are on the side of death, and losing their ability to offer independent critique and prophetic rigour, are real. Vellem 
articulated it as a caution; as a reminder that Black Theology of Liberation and its proponents were not pure but, like anybody else, tainted by virtue of being human; and that therefore a grounding and accountable spirituality was so crucial.

\section{False consciousness}

Much of Vellem's work, with reference to Biko, Boesak and others, focused on an illumination of the reigning false consciousness that kept the status quo in place. One of the clearest spaces in which he located such a consciousness was in the church (Vellem 2015c):

The church ... must be unshackled from false consciousness. (p. 5)

He saw fragments of such a consciousness in an 'ideologised religion in the context of a black led government'; the church being 'an instrument of cultural domination'; the church's 'complacency with a life-killing capitalist exploitation'; and the ways in which the church contributes to 'assimilate, coopt and destroy the cultural and psychological resources on which the previously oppressed have continued to survive' (Vellem 2015c). Certain forms of religiosity and colonial Christianity are breeding grounds for false consciousness that, in the language of Althusser, 'spawns "obedience," conformity and submissiveness' (Sefara 2020).

False consciousness is the internalisation of superiority or inferiority in an uncritical manner, failing to understand, or accept, that hegemonic power constructs societies and institutions deliberately in favour of some (white and male) whilst denying others their humanity (black and female). Such a false consciousness 'leaves the white value system intact' (Lamola 2017), often through dichotomised religious sensibilities that convince the oppressed that their rewards for bearing a cross on earth are waiting for them in heaven. False consciousness results in false humanity, or inhumanity, both for those living with 'racial superiority' and those living with 'racial inferiority' (Lamola 2017).

One of Vellem's biggest laments was how such a false consciousness was still dominant, not only in the white and black church, for that matter, but also in academic institutions, amongst public leaders in government or private sector, and in society at large. The pseudo-innocence that cultivates fertile soil for living unconscious lives (cf. Boesak 1977:3) - feigning innocence in the face of large-scale oppressions, and surrendering fatalistically to such oppressions - still reigns supreme in many spaces to this day. Instead of accepting the cards that were dealt as inevitable, Vellem points the way to a spirituality that breaks fundamentally with pseudo-innocence and false consciousness, fostering a consciousness that embraces the cross, retrieves the resurrection as rebellion, invites the imvuselelo as an exorcism of falsehoods and unfreedoms and reconstructs deliberately a new political community, with true humanity at the core of its imaginary.

\section{The cross as entering death}

In reflecting on the concrete instantiations of profound unfreedoms, named so bravely by Vellem, not only in his writings but also as an academic leader, he consistently drew from the wells of his own spirituality. To him the cross becomes identifiable in the concrete experiences of death being mediated in contemporary society (Vellem 2018):

The rejection of Jesus Christ - his incarceration, torture, and lynching on the cross - were consequences of his challenge of the status quo. Prayer is a subversive verb that collapses the chasm between piety and politics in protest for life against alienation, residential, worldly and global where the meaning of life is collapsed. Spirituality is the cohabitation of ideology and faith in which the aspirational promises of ideology shift their rationality to a faith that is fearless and doubtless in the embodiment of alienation. To embrace the cross is to return from the inner courtyard of the belief in the superiority of one race, 'dungeoning' ideology and faith in the 21st century. It is spirituality with verbs, not resignation, that instantiates the embrace of the cross. (p. 529)

Firstly, he speaks about the spirituality that intentionally embraces the cross (Vellem 2018):

A new spirituality embedded in the turbulent passages of the wretched, the black, inspires the verbs to return to the cross - the spiritual dimension of embracing the cross. (p. 515)

It is not a triumphant spirituality but 'a spirituality of woundedness' (Vellem 2014b). And yet, the way in which Vellem described this 'spirituality of woundedness' is not one of fatalistic surrender, apathy or victimhood, but the contrary. This spirituality, Vellem (2014b) wrote, 'harnesses life in the resources of African values' and finds expression in 'a refusal of the death of consciousness'. It might be a spirituality of the cross, marked by deep and perpetual wounds, but simultaneously, it is a subversive spirituality that refuses the death of consciousness, even amidst death, and gathers creatively the resources of African values to harness and mobilise life, even amidst death.

The subversion of the cross is not for nothing. It is with the express purpose to face and engage death, raging on the streets and in our institutions in ways seen and unseen, but also to learn how to die to the fear of death, in order to raise to life, freedom and new expressions of love.

One of the spheres in which death had to be faced and unmasked, in order to refuse a final blow to consciousness and authentic identity, is the sphere of African religiosity and ecclesiology. Vellem (2014b) shows how, for example, a 'salvationist, violent and subjugating form of Western religiosity' is countered by African Independent Churches, often counting its members from the poorest of the poor, yet resisting co-option into Western forms of Christianity that demands an expulsion of indigenous psycho-cultural and religious assets. It does so precisely by drawing from the wells of those inherent resources that colonial Christianity belittled and killed. 
The kind of spirituality Vellem speaks of here, as embracing the cross, is not a passive embrace of fate. It is the complete opposite. Entering death, in this sense, is to participate with Christ in arresting the power death has over us. It is to refuse the forces of death and to mobilise and galvanise, even in and surrounded by death, all the possible resources to our avail, to be able to outwit death's sting.

Therefore, then, Vellem spoke about 'un-thinking the West' not only a nice-sounding intellectual category coming from the bowel of pain and anger, but also as a spiritual practice to be fostered with great intention (Vellem 2017):

Un-thinking the West is not only cognitive but also spiritual. Umoya, the spirit of life ... to un-think the West, constitutes inter alia, the rejection of Hellenocentric concepts as a starting point of knowledge. Umoya should reject the self-serving periodisation of history centred on Europe, dualistic obfuscating secularism and willingness by black to occlude their knowledge systems.

The Spirit, amidst death, has to enable such a refusal or outright rejection of that which is out to kill the soul. Vellem argues that without such intentional refusal of death, liberation would remain elusive (Vellem 2017):

Without this ... the lethargic sleep, the mocking laughter of the West at the self-wounding black African remains a syndrome that arrests the translation of liberation knowledge from history.

Embracing the cross is an embrace of both pain and anger: the pain of themany deaths and unfreedoms and theinsurmountable anger at that which causes is often in such calculated and knowing ways. The thread running through all the expressions of rage and resistance, voiced and lived by Vuyani, was his deep longing for life and freedom. Raging at unfreedoms that mediate death, in the case of Vellem, came from a place of deep love:

I wish I could share

All the love that's in my heart

Remove all the bars that keep us apart

And I wish you could know how it is to be me

Then you'd see and agree that every man should be free. (Simone 1967)

\section{Resurrection as rebellion against death}

Vellem (2015b) understood God 'as God of life and this understanding of life is not an abstract but material, bodily life'.

In contrast, the Empire is 'death dealing and life killing' (World Alliance of Reformed Churches 2004). With reference to the Accra Confession, Vellem (2015b) states that '(t)he cry for life by nonpersons on which Black Theology of liberation has constantly reflected is therefore a cry for God to be the God of life'.

Subjected to Empire, but confessing a God of life, evokes a deep cry for this God to be who this God is!

This is not a passive cry however, but a cry that at once assumes responsibility to act in a way that will unmask death and its power, whilst choosing to stand on the side of life (Vellem 2015b):

As a theology of life, the cry for life by those living in conditions that are life killing, as we have already said - not a passive cry provides the active artefacts of critical consciousness and transformation as the nonperson becomes an agent of his or her life. Ngungi Wa Thiongo (n.d.:10) makes this point poignantly: 'one is transformed by that act of trying to transform'. (p. 6)

In such an active cry for liberation - expressed in life and freedom in abundance - people and movements are going through processes of critical consciousness, according to Vellem, in which they themselves are transformed, as they seek for transformation. One can also say that in the acts of working for liberation, we ourselves are standing a chance of being liberated from our 'fear of death'.

Vellem then refers to Gutierrez (2007:11) who says, ' $r$ r esurrection is the victory of life over death, while poverty means simply death'. The resurrection does not allow us to accept the death of poverty or inequality but to resist it, where it threatens life and freedom. Again, resurrection in this sense is not only a spiritual or mystical or transcendental category, but also one that invites us to participate today in Christ's resurrection, in a very concrete sense - spiritually, mentally and physically.

Just as an embrace of the cross is to deeply immerse ourselves in the multiple deaths dealt to communities, people and the planet on a daily basis, the resurrection is an embrace of resistance against every form of death and unfreedom that shatters the possibility of life and freedom in abundance.

For Vellem (2015b), resurrection meant a profound sense of rebellion:

There is a sense in which resurrection is rebellion and in the struggles for life, the nonperson rebels against the life killing sprit of Empire. Rebellion against death is to live in the context of Empire without the ideals and notions of Empire. Rebellion against death is to deny victory to torture and starvation in the context of the militarisation of life by Empire. Rebellion against death is bodily resurrection. (pp. 5-6)

Vellem (2015b:6) then evokes Wa Thiongo (n.d.), when he states:

The cry for life as rebellion and thus insurrection against life killing systems is 'the capacity of the oppressed to change the conditions of their being and in the process change themselves'. (p. 27)

What is important to note in both Vellem and Wa Thiongo is an emphasis on the oppressed themselves, being raised from slavery or defeatism or victimhood, rebelling against lifekilling systems that kept them down and aimed at killing their souls. Theirs is not waiting passively on the Empire to do them any favours, but an active resistance of the deathdealing forces of Empire, acting 'to change the conditions of their being' and, says Wa Thiongo, 'in the process change themselves'. As those who are oppressed participate in 
resisting death, they participate in Christ's resurrection, and as they do so they are conscientised into a new way of being - a new condition that stands tall in the face of death's mocking laughter, to laugh back.

Herein lies one of the keys to an understanding of Vellem's work and commitments. He is not regarding what he is busy with as mere intellectual constructs giving rise to new theory, which might or might not be considered as part of a revolutionary alternative. Instead, this is to participate in the rebellion from below that finds expression in peoples all over the world that daily find in themselves and how they organise, ways to resist death tenaciously (Vellem 2015b):

In unmasking the universe of Empire and its mindset, there is no theory but the praxis of the peoples of the South and all those totally excluded and oppressed, living on the underside of modernity with its effects of racism and capitalism. (p. 6)

Some in the corridors where he moved became irritated and anxious even - at his sharp critique and perpetual unmasking of the ways of Empire and its tentacles, infiltrating our worship spaces, and academic institutions, and governance chambers. He could see what others could not; he could read beneath the surface; he could hear between the lines. His was a daily existential battle against subtle and blatant forces of death, pushing back with all his might, until his body became too frail to do so any longer.

If one participates with a people who occupy 'the underside of modernity', experiencing the 'effects of racism and capitalism' perpetually, and sensing these forces keeping their feet on the necks of the (black) poor and women and children alike, sucking dry the lifeblood of the earth through greedy occupations and neo-colonisations, the burden becomes unbearable, the anger becomes tangible and the urgency becomes unpalatable. To then be met with the decency of apathy, and the patience of complicity, and the falsehoods of Empire theology - often hidden neatly behind sophisticated constructs - is to embrace a cross, and to be at war at 'the underside' where evil flourishes, rebelling, resisting, hoping for the new day to break.

Maybe it is the unbearable burden of the cross, which made Vuyani yearn so much for a spirituality authentic to liberation. He knew that this alone would carry one through (Vellem 2015b):

The spirituality for life in a Black Theology of liberation is, amongst others, the energy to holding on to life in conditions of death. All of life is regarded as spiritual without any dichotomies; hence, a cry for life and that power to resist death, providing strength to live, puts our understanding of God as embedded in the struggles of the marginalised. Jesus becomes the rootage of this spirituality, Jesus who faces the same struggles in life that the nonpersons face. (pp. 1-6)

For him, the cross Jesus had to bear, took Jesus to 'the underside' of the city, to the darkest side of history, to a place where Jesus could confront the universal struggles of all those marginalised and killed by the forces of Empire (Vellem 2015b):

The biblical hermeneutics of a Black Theology of liberation moves from within the context of the cry for life by the poor. (pp. 1-6)

Once one embraced Jesus at the cross, and discovers in the cry for life by the poor the present cry of Jesus, one can never read the Bible or interpret ecclesial expressions or make sense of the global city, in the same way again. From the 'underside of modernity', everything looks completely different.

\section{Liberation through imvuselelo: A reclamation and practice of life and freedom}

A spirituality of liberation is a spirituality of life and freedom. Yet, stating that alone could foster escapist spiritualities.

A spirituality of liberation, before it can speak about life and freedom, starts in deep solidarity with the living dead and the multiple overlapping unfreedoms that rob the majority peoples of the world of joy and dignity. It starts therefore in an embrace of the cross (Vellem 2018:515-529).

A spirituality of liberation, to be liberating, has to be fostered through an encounter with death in all its many forms including one's own death, of consciousness, of soul and intently, of the fear of death itself. It is a spirituality that insists on the resurrection as rebellion, resistance and subversion of death. It is at once 'the spirit of refusing to die the death of a slave!' (Vellem 2018).

Such a spirituality that (1) embraces the cross in solidarity with death and unfreedom, whilst (2) refusing to surrender to 'the death of a slave', but (3) vehemently resisting it through the rebellion and subversion of the resurrection, is activated by the imouselelo [revival] of the Spirit.

As I wrote this, Covid-19, anti-racism protests and Pentecost Sunday were all fused in my own mind and spirit. In revisiting Vellem's doctoral thesis, I was deeply moved by the centrality of the imouselelo and the place of the Spirit.

As I would emphasise in the next section of this article, Vellem did not only deconstruct dominant expressions of power, but also meditated upon newness of life and mediations of freedom, made possible by a retrieval and reinterpretation of African religious sources for contemporary societal challenges. Consistently in his articles, lectures and speeches, he made use of African vocabulary and symbols in ways that re-asserted their meanings for today.

Vellem (2007:291) speaks about the imvuselelo as a 'distinct liturgical symbol' cultivating umanyano [unity]. It was in the ritualistic expression and enactment of the imvuselelo that unity, integration and wholeness were shaped. 
And yet, after stating this, rather orthodox assertion, Vellem then reframes the imvuselelo in a way that in my mind has been lost to the average ecclesial expression, in which the imvuselelo often got reduced to a vibrant fundraiser, void of the spiritual, ethical and political content Vellem so powerfully assigns to it.

Vellem reframes the imvuselelo altogether, refusing to reduce it to a narrow spiritual category of escape (which in itself is often more than what it has in reality been reduced to even). Vellem (2007:292) instead describes the imouselelo as the 'rich dangerous memory of restlessness and insanity in the midst of oppression'. He speaks of it as 'a rich, impatient, insurgent and dangerous memory of the spirit that refuses to be relegated to the grave and the hillside' (Vellem 2007:292). In his contemplation of imvuselelo, there is a close proximity - oneness even - between the Spirit and the memory, restlessness and insanities of experiences of oppression.

This is what the imvuselelo is (Vellem 2007):

Imvuselelo is the death of a spirit of death (ifufunyane) and the revival of home for the indwelling and liberation of the spirit. (p. 292)

Vellem's constructs were often such that mere mortals like most of us could not grasp the depth of meaning and nuance at first, and, often, never fully. His writing was difficult yet poetic. It was often extremely clear, but sometimes, I suppose, allowed the reader and listener the space to make our own meaning as we engaged with the layers hidden behind his speech.

What comes to me in the context of that phrase of his is that the imouselelo is an exorcism of the spirit, mentality and consciousness of death - which includes the death of dignity, the succumb to victimhood and the reliance on external forces, on the one hand; and, on the other hand, a revival of a new form of home or consciousness - wherein the Spirit dwells in a profoundly and continuously liberating and liberationist manner, affecting the totality of life.

The imvuselelo, in its exorcism, is to 'unlearn the death of a slave' and to be deconstructed from the ways in which colonial, patriarchal and human-centred Christianities and sensibilities have constructed us. The imouselelo, in its revival, is to not leave a vacuum to be filled by new and cruel slavemasters again, but is to be reconstructed and remade in a way that will be 'moral and integral in the midst of immorality and disintegration' (Vellem 2007:292).

The imvuselelo as a symbol of unity - of gathering together is not only gathering a people called from death to life together - but it is also to reintegrate that which was disintegrated by a colonial consciousness; to resist the death of the soul trough immorality and disintegration and to be revived into life and freedom marked by morality and integration; or totality, or wholeness (cf. Vellem 2007:292).
For Vellem (2007:292), imvuselelo is at the core of a spirituality that transcends death and mediates life: 'imvuselelo is the beginning of the breath of life, the ruach of life in the face of the tangent of death'. This to me captures something of Vellem's vision, and we will do well to meditate upon it for our own praxis in South Africa and the world today.

I conclude this section with a last note on the imvuselelo. Vellem (2007:293) values spirituality in how it relates to tradition, or hands down values and meaning from one generation to the next, through rituals. In this sense, then, imvuselelo is also 'imbibing and drinking from the well of the "restless memory" that needs to be inserted in the remaking of our public life' (Vellem 2007:293). It is to drink from the well of those that have gone before us in the different global struggles of liberation, to be disrupted and re-oriented by their restlessness, as well as the memory of those today who under harsh conditions resist the death of the slave, in its many different expressions.

It is the fellowship of the shaken in which the Spirit establishes within this fellowship 'a new dynamism' with profound effects on the politike koinonia (Vellem 2007:293). Imvuselelo is the space in which the fellowship or community of the shaken is imbibed with the restless memory of the cross and resurrection, in such a profound way that the very shaken community can start to shape an alternative political community.

\section{Reconstruction}

It is important to note, and this might not always have been as visible in his theology, that Vellem (2007:307) spoke about Black Theology of Liberation and its task as 'the reconstruction, rebuilding and revival of publics in civil society'. Instead of understanding BTL, therefore, only in the sense of critical analysis or deconstruction, or prophetic speech as naming death, here Vellem provides a profound imagination of a radically different kind of civil theology that gives birth to a new political community and agency. Prophetic speech now becomes the revived embodiments of a civic and public life that oozes with life, in the face of - and outwitting - death.

It is in the 'solidarity of the shaken' - or 'the least of these' or 'the wretched of the earth' - that the imouselelo breathes new life. Vellem (2007:308) poetically described it, saying such imvuselelo is like 'the iziko of the arche of a political community' (translated: such a revival is like the fire that starts or begins a new political community).

For Vellem, the imvuselelo is therefore never an innocent, otherworldly affair of escapist rituals but an engaged affair with the realities of the lived dead today, in the here and bow, building solidarity, in which an iziko or fire is ignited, that burns into being a new political community - one that is able to reconstruct, rebuild and revive a civil society that participates through a new and revived morality and integration, mediating a profound sense of wholeness (cf. Vellem 2007:308). 
Black Theology of Liberation, instead of being destructive or angry only, is that which animates - through anger, pain and love consumed by the imvuselelo and transformed into life-breathing substance - all of the above, being and becoming 'sane, constructive but restless' (Vellem 2007:308). This restlessness of Black Theology of Liberation should not be misunderstood for destructiveness, but needs to be seen for the urgency with which it seeks to animate life and arrest death.

\section{Fusing piety and politics}

Vellem's longing for liberation was anchored in his deep spirituality, and his understanding of the task of Black Theology of Liberation as the rebuilding, reconstruction and revival of different publics, in ways that foster morality and integration, stemmed from his insistence that piety and politics, prayer and public life, spirituality and transformation, should never - in the world of African people of faith - be separated (Vellem 2018):

Spirituality thus combines piety and politics, what rootless people in ekassie think and pray about God and Jesus as they struggle to author and regain their authority as human beings. (p. 521)

For Vellem, both the multiple and overlapping struggles against death, and the longings for life and freedom, were never only physical struggles, because he did not hold this dichotomous idea of life but rejected it vehemently, based on his understanding of a God who permeates all of life (Vellem 2018):

The struggle against spiritual impoverishment, residential racism, and alienation is not only a political struggle but an intrinsically and inseparably pietistic spiritual one, thus rendering prayer as a struggle - a struggle for life. (p. 520)

Vellem's thought on this finds resonance in the earlier work of Sobrino (1988), entitled Spirituality and liberation: Toward political holiness. Sobrino brought politics and holiness into the same sentence, just as Vellem does with politics and piety. The separation of these is the product of false dichotomies born from Greek philosophy, yet, contradicting prophetic traditions that embrace all of life. The Spirit [ ruach] of Vellem's imvuselelo is hovering over the polis and breathing into the polis, and rising up from within the cries and longings and unfreedoms of the wretched of the polis, to give utterance to a new polis.

\section{Religionless speech}

In his doctoral thesis, Vellem (2007:330) said, 'public theology should learn to speak "religionlessly"'. He regarded Black Liberation Theology as an endeavour of 'learning to speak the language of the people beyond confessional vagrancies' (Vellem 2007:330).

I found this an interesting term used by Vellem, and wish I could ask him what he exactly meant when using it. My reading of him is that he spoke about the limits of confessional languages, in the face of a larger public life or the political community, and, that theology, in public spheres, needed to be practised not only 'religionlessly' but also outside and beyond the narrow - and often arrogant - confines of confessional language.

At the same time, it was an insistence to learn the languages of those excluded from the polis - the 'least of these' - in order for their words and longings to reverberate through the corridors and rooms where policies are considered and polity is made.

This was not only a strategic-pragmatic consideration, which I argue it is, but also an epistemological-prophetic consideration, asserting the wisdoms and experiences of the silent masses and allowing for their speech to disrupt and transform how we speak.

\section{Resources for liberation reconstruction: Own agency and moral consciousness}

Vellem (2014b) insists that African religiosity and expressions do not need validation from Western frameworks, but need to be asserted with 'equal recognition as a value system among others'. It contains the 'resources for cultural liberation, African history, black African agency and moral consciousness' (Vellem 2014b). It only needs to be acknowledged by those embedded in it, retrieved and mobilised, to become a potent 'resource for an alternative civilisation in the context of Empire' (Vellem 2014b). The reconstructive work flowing from liberation is not a tame exercise, but in Vellem's work contained the imaginary of an alternative civilisation - a potent new political community subverting the rules and knowledge systems and values of Empire (Vellem 2017):

It is indisputable that Black Theology of Liberation (BTL) intentionally un-thinks the West. BTL has its own independent conceptual and theoretical foundations and can hold without the West if it rejects the architecture of Western knowledge as a final norm for life. This, however, is a spiritual matter ... (pp. 1-9)

Again, and over and over, Vellem emphasises that these are not only intellectual constructs or matters of materiality, but this too, he contends, is a spiritual matter. The rejection of Western knowledge 'as a final norm for life' and the embrace of an alternative consciousness that refuses dichotomisation of life is a spiritual matter.

In this sense, Vellem (2017) continues to say, part of the slowness of liberation might be 'self-inflicted' by proponents of this school:

At a time when neofascism, which is virtually an open display of psychological and ideological confusion, racism, classism, sensibilities of integralism and gender violence, having become rife, liberal democracy is arguably in crisis today. BTL has to move beyond rethinking and repeating its tried and tested ways of response to black pain caused by racism and colonialism. (pp. 1-9) 
My sense of his argument here is that liberation remains elusive when own agency is not fully embraced, moral consciousness harnessed and practised, in the direction of embodied alternatives. I also read it as Vellem saying new languages and forms of expression need to be found by Black Theologies of Liberation today, 'beyond rethinking and repeating its tried and tested ways', if it is to not only name and deconstruct edifices of power and systemic exclusion but also contribute to reconstructed realities.

\section{Liberation and reconstruction}

Perhaps, it is important to make a last note in this regard, seeing that liberation and reconstruction theologies have not always sat well alongside each other. Without going into a long treatise on this debate, I would restrict myself to a few short paragraphs.

The proposed shift from liberation to reconstruction, as articulated prominently by Mugambi (1995) and VillaVicencio (1992), was rejected by researcher like Maluleke (1994, 1997) and others, contending a departure from a hermeneutic of suspicion, and a low appreciation for the centrality - and prerequisites - of liberation and inculturation, even in post-colonial contexts, in theologies of reconstruction. Part of the critique Villa-Vicencio levelled at liberation theologies, in turn, was their lack of 'strategies of reconstruction', which in post-colonial contexts became essential (cf. Vellem 2007:139).

Vellem (2007:128-237) devotes a whole chapter of his thesis to engage in critical dialogue with the categories of liberation, reconstruction and development.

Vellem, aligned to my reading of him in the previous paragraphs, argued that 'the essence' of Black Liberation Theology as a paradigm need not be redefined in postcolonial or post-apartheid contexts, 'but the mode of Black Theology and liberation' (Vellem 2007:128) required a shift 'to a less-embittered approach with a kind of "constructive impatience"'.

Vellem (2007) states that 'reconstruction must begin with liberation', and this assertion is fundamentally different from the argued 'shift from liberation to reconstruction':

\footnotetext{
... The statement that reconstruction must begin with liberation implies that reconstruction is not a quid pro quo for liberation, but that liberation is a sine qua non of reconstruction. Liberation is the framework within which reconstruction and development can find their place. (p. 131)
}

The resurrection would not have been a victory was it not for the viciousness of the cross. Embracing the cross and renouncing death in the face of death is, in Vellem, a sine qua non for resurrection. The cross becomes the framework within which the resurrection should be understood as rebellion, and the imvusulelo as exorcism and reconstruction. However, and this is important, liberation theologies now also need to be more vigilant in imagining alternative to Empire in 'prophetic pragmatic' ways (cf. West 1989:211239), and constructing reconstructive proposals, to call those alternative imaginaries into being.

\section{A broadened longing for freedom: The intersectionality of violence and oppression}

In recent years, Vellem became more assertive about the intersectionality of violences and oppressions dealt by the forces of Empire. This was another way in which he helped led Black Liberation Theology into embracing a broader agenda (De Beer 2019):

Increasingly he worked on the intersections of race, class, gender, land and earth. His theological insights were saturated with African wisdom, an embrace of the 'kraal' amidst 'mekhukhu' and 'eKasi' - a disruption of Empire's deadly and all-embracive exclusions. He insisted on finding life, in the harshest of places; on claiming it, celebrating it, and sharing it.

He did so also in conversation with the work and assertions of the late James Cone. Vellem (2018) said this about Cone:

$[I] \mathrm{n}$ his own words, he wrote, spoke, taught and waged the struggle for the $[B]$ lack, women degraded by patriarchal bigotry and violence, the LGBTIQ communities, the differently abled people, the uprooted in Iraq and Afghanistan, Syria, minjung in Korea and the Dalit in India, yes, the marginalized and victims of the colonial matrix of power in our world today. (p. 2)

Not only does he retrieve in an appreciative way Cone's engagement with what he calls 'the colonial matrix of power', but he also locates Cone's work in global solidarity with oppressed and dislocated people globally, beyond only the experiences of Black North America.

Vellem further elaborated upon his assertion that Black Liberation Theology had to practise a fuller embrace of all oppressed peoples and places everywhere by drawing upon the work of Enrique Dussel and other proponents of the Latin-American Decoloniality Project. In fact, in the beautiful and far-reaching interview with Martin Laubscher (2018:13), Vellem indicated that he intended to remain in close dialogue with this school.

Attending closely to the work of Dussel, Vellem (2015b) retrieved these words of Dussel (2011):

What the liberation of diverse types of oppressed and/or excluded populations presupposes is the overcoming of cynicalmanagerial reason (planetary administrative) of capitalism (as an economic system), of liberalism (as a political system), of Eurocentrism (as an ideology), of machismo (in erotics) of the reign of the white race (in racism), of the destruction of nature (in ecology), and so on. (p. 111)

Riffing off Dussel, Vellem (2015b) then explains:

Black Theology of Liberation situates race analysis in modernity and envisions knowledge forms that seek to overcome the 'reason' of capitalism, liberalism, macho power, Eurocentrism, racism and 
ecocide, politically and theologically, to mention but a few. In this light, we situate the ponderings of racism and neoliberal economics within Western modernity, ipso facto, the ponderings of apartheid and its residues in post-1994 South Africa. Stated otherwise, the anatomy of whiteness is racism. (pp. 3-6)

Here one can see not only the deep influence of Dussel on Vellem's intersectional insistence, but also how Vellem sought to open up space hospitably for new and expanded horizons within the praxis of Black Liberation Theology.

Vellem shifted his own horizons not only to include issues of gender more intentionally in his own work, but his theological imagination also started to reflect more consciously on creation and the ways in which Empire, patriarchy and white supremacy gave rise to killing machines that had a universal effect on all of life - human and non-human. In his reflection on spirituality from the cross, Vellem (2018) offers this poetic lament of creation:

The skies are throttled, mountains are crumbling, rivers, streams, oceans, and the deeps that 'bowed' in prayerful glory to God - a classical Reformed view of the order of creation in mind - are left roaring in drought, while the waters of the seas with their waves lifted on high to intrude the earth are slowly rising to rupture the boundaries between the earth and the sea. Creation is groaning, as the Accra Confession rightly states, and indeed, we live in 'an era in which human activities have become the most determinant factor in shaping how the planet behaves'. (p. 516)

Just as racism and its sponsor of white supremacy could only be confronted and defeated through a spiritual conversion, in Vellem's mind, so too the oppression of women and all creation - indeed the ways of Empire at large - were spiritual matters that required a spiritual revolution if physical, spatial or bodily transformations were to be realised. A spirituality of liberation is a spirituality of life and freedom, embracing the cross; the resurrection as rebellion; and the imvuselelo as a place of conscientisation and decolonisation - indeed, the beginning of a new political community (Vellem 2015b):

In these adverse catastrophic experiences of black Africans, women and creation, the energy to hold on to life is our method of spirituality for life. Unmasking the husk of Empire is a spiritual matter for decolonisation. (p. 6)

\section{When will freedom come...?}

Racism is a spiritual matter. Renouncing a monopoly of Western knowledge and value constructs is a spiritual matter. Decolonisation is a spiritual matter. Materiality and bodiliness, and the violent extraction from the earth and femicide at levels never seen before, is a spiritual matter. The disintegration of morality in public life is a spiritual matter. The shackledness of churches and the managerialist university are spiritual matters.

Engaging darkness and death - as these are spiritual matters manifesting materially and concretely - could be souldestructive if done without a spirituality of the cross and the resurrection, held together and animated in the imvuselelo, where the iziko is ignited and kept burning: burning into being a new political community in which spirituality and materiality are interwoven:
I wish I could give
All I'm longing to give
I wish I could live
Like I'm longin' to live
I wish I could do
All the things that I can do
Though I'm way overdue
I'd be starting anew (Simone 1967).

Vuyani, you gave all you could give; you lived all you could live. You embodied what you wrote. You became the ritual that passed on meaning and values to a next generation. On 04 December 2019 you started anew, and what was overdue for those left behind, we need to take up now, to keep your legacy and iziko alive:

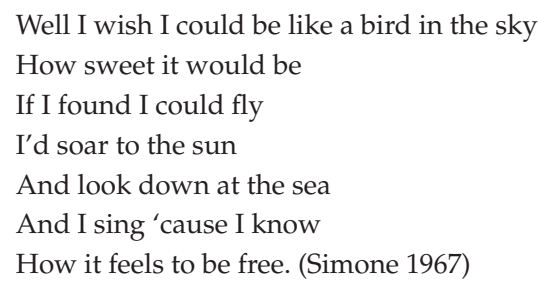

When Vuyani started with a chorus, the imouselelo could begin. When we remember him, the imvuselelo can begin. The best way to keep alive the restless memory of Vuyani Shadrack Vellem would not only be to read his work, and deliberate about the pureness, or not, of his version of Black Theology of Liberation. The best way might rather be to embrace the many crosses we see, there to resist with the living dead, until they too - like Vuyani - can feel how it is to be free. It is a concrete spirituality, born from lament, daring to hope, refusing the death of consciousness.

\section{Acknowledgements}

The author acknowledges the professional services of the language editor.

\section{Competing interests}

The author has declared that no competing interests exist.

\section{Author's contributions}

I declare that I am the sole author of this research article.

\section{Ethical consideration}

This article followed all ethical standards for a research without direct contact with human or animal subjects.

\section{Funding information}

This research received no specific grant from any funding agency in the public, commercial or not-for-profit sectors. 


\section{Data availability statement}

Data sharing is not applicable to this article as no new data were created or analysed in this study.

\section{Disclaimer}

The views and opinions expressed in this article are those of the author and do not necessarily reflect the official policy or position of any affiliated agency of the author.

\section{References}

Boesak, A.A., 1977, Farewell to innocence: A socio-ethical study on black theology and black power, Orbis Books, Maryknoll, NY.

Cone, J.H., 1980, The black church and Marxism: What do they have to say to each other?, Union Theological Seminary, New York.

De Beer, S., 2019, Warm heart; sharp mind; frail body - Black prophet treading where others do not dare, Centre for Contextual Ministry, University of Pretoria, viewed 09 December 2019, from https://www.up.ac.za/centre-for-contextual-ministry/ news/post 2863707-warm-heart-sharp-mind-frail-body-black-prophet-treadingwhere-others-do-not-dare...

Dussel, E., Lanham, M.D., 2011, 'The "world-system": Europe as "center" and it "periphery" beyond Eurocentrism', in J.T. Levy \& M.I. Young (eds.), Colonialism and its legacies, pp. 97-120, Lexington Books, Lanham, MD.

Eagleton, T., 2010, 'The death of universities', The Guardian, 17 December, 2010 viewed 18 April 2020, from https://www.theguardian.com/commentisfree/2010/ $\mathrm{dec} / 17 /$ death-universities-malaise-tuition-fees.

Gutierrez, G., 2007, 'Liberation theology for the twenty-first century', in P.H. Closkey \& J.P. Hogan (eds.), Romero's legacy: The call to peace and justice, pp. 1-30, Rowman \& Littlefield Publishers, Lanham, MD.

Khumalo, T., 2019, 'South Africa declares "Femicide" a national crisis', VOA News, 20 September 2019, viewed 05 May 2020 from https://www.voanews.com/africa/ south-africa-declares-femicide-national-crisis.

Kritzinger, J.N.J., 1988, 'Black theology: A challenge to mission', Unpublished DTh thesis, Dept. of Missiology, University of South Africa, Pretoria.

Kritzinger, J.N.J., 1990, A theological perspective on white liberation, Centre for Contextual Hermeneutics, University of Stellenbosch, Stellenbosch.

Lamola, M.J., 2017, Black solidarity and the quest of a non-racial humanity: Biko's enduring political dilemma, Institute for African Alternatives, viewed 06 Decembe 2017, from https://ifaaza.org/2017/12/06/black-solidarity-and-the-quest-of-anon-racial-humanity-bikos-enduring-political-dilemma/.

Laubscher, M., 2018, 'Interview with Vuyani S. Vellem', Acta Theologica 38(1), 1-14 http://doi.org/10.18820/23099089/actat.v38i1.1

Maluleke, T., 1994, 'The proposal for theology of reconstruction: A critical approach', Missionalia: Southern African Journal of Mission Studies 22(3), 245-258.
Maluleke, T., 1997, 'Half a century of African theologies', Journal of Theology for Southern Africa 99(1), 4-23.

Mugambi, J.N.K., 1995, From liberation to reconstruction. African Christian theology after the Cold War, East African Educational Publishers, Nairobi.

Roser, M., Ritchie, H., Ortiz-Ospina, E. \& Hasell, J., 2020, 'Coronavirus pandemic (COVID-19), statistics and research', Our World in Data, viewed 12 June 2020, from https://ourworldindata.org/coronavirus.

Sefara, M., 2020, 'A false consciousness', Sunday World, viewed 01 June 2020 from https://sundayworld.co.za/opinion/a-false-consciousness/.

Simone, N., 1967, Nashville I wish I knew how it would feel to be free, Silk \& Sou (album), RCA Records, Nashville.

Sobrino, J., 1988, Spirituality of liberation: Toward political holiness, Orbis Books, Maryknoll, NY.

Vellem, V.S., 2007, 'The symbol of liberation in South African public life: A Black theological perspective', Unpublished PhD thesis, University of Pretoria, Pretoria.

Vellem, V.S., 2014a, 'The task of urban black public theology', HTS Teologiese Studies/Theological Studies 70(3), Art. \#2728, 1-6. http://doi.org/10.4102/hts. v70i3.2728

Vellem, V.S., 2014b, 'Spirituality of liberation: A conversation with African religiosity' HTS Teologiese Studies/Theological Studies 70(1), Art. \#2752, 1-7. http://doi org/10.4102/hts.v70i1.2752

Vellem, V.S., 2014c, Modern slavery in the post-1994 South Africa? A critical ethica analysis of the NDP promises for unemployment in South Africa, Koers - Bulletin for Christian Scholarship 79(2), Art. \#2163, 1-8. http://doi.org/10.4102/koers. v79i2.2163

Vellem, V.S. 2015a, 'Black theology of liberation and the economy of life', The Ecumenical Review 67(2), 177-186. https://doi.org/10.1111/erev.12149

Vellem, V.S., 2015b, 'Black theology of liberation: A theology of life in the context of Empire', Verbum et Ecclesia 36(3), 1-6. https://doi.org/10.4102/VE.V36I3.1470

Vellem V.S., 2015c, 'Unshackling the Church', HTS Teologiese Studies/Theologica Studies 71(3), Art. \#3119, 1-5. https://doi.org/10.4102/hts.v71i3.3119

Vellem, V.S., 2017, 'Un-thinking the West: The spirit of doing Black Theology of Liberation in decolonial times', HTS Teologiese Studies/Theological Studies 73(3), a4737. https://doi.org/10.4102/hts.v73i3.4737

Vellem, V.S., 2018, 'The spiritual dimension of embracing the cross', Internationa Review of Mission 107(2), 515-529. https://doi.org/10.1111/irom.12247

Villa-Vicencio, C., 1992, A theology of reconstruction: Nation-building and human rights, Cambridge University Press, Cambridge.

Wa Thiong'o, N., 2009, 'Recovering our memory: South Africa in black imagination', in Steve Biko Foundation (ed.), The Steve Biko Memorial Lectures 2000-2008, pp. 51-72, Pan Macmillan, Johannesburg.

Wa Thiongo, N., n.d., In the name of the mother: Reflections on writers and empire, James Curry, Nairobi.

West, C., 1989, The American Evasion of philosophy: A genealogy of pragmatism, University of Wisconsin Press, Madison, WI.

World Alliance of Reformed Churches, 2004, The Accra Confession, Adopted by the 24th General Council of the World Alliance of Reformed Churches in Accra, Ghana, viewed 8 April 2020 from http://wcrc.ch/accra. 